\title{
Efficacy of Different Fungicides against Exserohilum turcicum Causing Turcicum Leaf Blight Disease in Maize
}

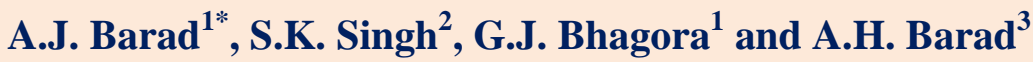 \\ ${ }^{1}$ Department of Plant Pathology, Anand Agricultural University, Anand-388110, \\ Gujarat, India \\ ${ }^{2}$ Main Maize Research Station, Godhra, Anand Agricultural University, Anand, India \\ ${ }^{3}$ College of Horticulture, Anand Agricultural University, Anand-388110, India
}

*Corresponding author

\section{A B S T R A C T}

Keywords

Maize, Exserohilum

turcicum, Northern corn

leaf blight, Fungicides,

Disease severity, Yield

Article Info

Accepted:

04 July 2019

Available Online:

10 August 2019
Among fungicides treated plots the grain and fodder yield of maize were significantly higher and disease severity is minimum than control. Among tested fungicide minimum disease severity (18.15\%), maximum grain yield (38.71 q/ha) and fodder yield (182.75 q/ha) was recorded in azoxystrobin $18.2 \%$ + difenoconazole $11.4 \%$ SC followed by tebuconazole $25.9 \mathrm{EC}$ and hexaconazole $5 \mathrm{SC}$. Least effective fungicide is azoxystrobin $23 \mathrm{SC}$ with $25.71 \%, 23.77$ and 90.29 q/ha of disease severity, grain yield and fodder yield, respectively. The maximum percent grain yield and fodder yield were recorded in azoxystrobin $(18.2 \%)+$ difenoconazole $(11.4 \%)$ SC with $51.30 \%$ and $52.46 \%$ and minimum in azoxystrobin 23 SC with $20.69 \%$ and $3.76 \%$ increase over control.

\section{Introduction}

Maize is known as "Queen of cereals" by virtue of contributing to about one-third of its production. Exserohilum turcicumcause the most serious fungal disease in maize crop is turcicum leaf blight also known as northern leaf blight.Maize is a member of the grassy family Poaceae. There is no any cereal, which has so immense potentially as to maize and also gives high biological yield as well as grain yield. However, here various factors are culpable for low productivity of maize, among them diseases are major constraint. Turcicum leaf blight (TLB) is a foliar disease caused by Exserohilum turcicum (Pass.) Leonard and Suggs is the most serious fungal disease of this crop. Severe losses in grain yield of maize crop due to epidemics of turcicum leaf blight disease and these losses up to 25 to $90 \%$ depending upon the severity of the disease (Chenulu and Hora, 1962; Jha, 1993). So the management of the disease through various method is essential. Among them most effective and fast result is get by using of fungicide, which give knockdown, rapid and 
effective result than other methods viz. cultural, mechanical and biological method. Kumar and Mauriya (2015) found that zineb and mancozeb like fungicide is effective reducing severity and ultimately produced higher grain yield of maize. Although, fungicide spray at required and recommended dose should be spray otherwise side effect and residual effect of fungicidal spray will be occurred. So far, the management of this disease by fungicide is most effective. Therefore, the present research work was undertaken for management of the turcicum leaf blight through various fungicide and find out which one was most effective against this disease.

\section{Materials and Methods}

The field experiment was conducted at Main Maize Research Station (Godhra), Anand Agricultural University, Anand during kharif 2018 against turcicum leaf blight disease of maize caused by Exserohilum turcicum. The experiment was laid out in randomized block design with 10 treatments as presented in Table 1. The treatments was consisted nine fungicides as treated plot and one untreated plotas control with each treatment of three replication on maize variety GM-6 (Gujarat Makai-6). The gross plot size $5.0 \times 3.6 \mathrm{~m}^{2}$ and net plot size $4.6 \times 2.4 \mathrm{~m}^{2}$ was maintain for proper plant growth. Crop cultivation carried out according all scientific recommended package of practices for maize production. The spray of artificial inoculum was inoculated after ten days old culture of $E$. turcicum followed by water spray to maintain humidity for infection and creating disease pressure or artificial epiphytotic condition in field.

The inoculum of the pathogen was prepared by multiplying culture of the pathogen on sterilized PDA medium. Before inoculation, water was sprayed on the leaves surface to maintain uniform moisture. The plots were applied two spray with different fungicides at 15 days interval starting from 40 days after sowing i.e. at 40 and 55 days after sowing. Ten plants from each replicated plots were randomly selected and tagged for recording observations on disease severity. Observations were recorded percent disease index (PDI), grain yield and fodder yield. Percent disease index (PDI) was calculated at the time of disease initiation and seven days after each spray of treatment.

The disease severity was recorded with the help of 1-9 rating scale. The scale consisted of nine class of categories and designated by Chung et al., (2010) and Mitiku et al., (2014). Calculate percent disease index (PDI) by using following formula of Wheeler (1969).

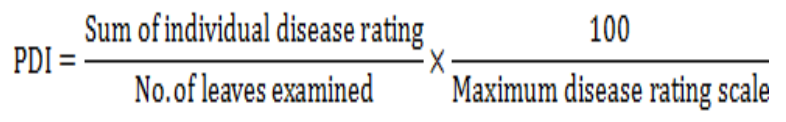

The percentage disease control was calculated with the help of following formula (Mathur et al., 1971).

Disease control $(\%)=\frac{\text { PDI in control }- \text { PDI in treatment }}{\text { PDI in control }} \times 100$

After harvesting, the cobs separated from plants as treatment wise from net plot basis were sundried, cleaned thoroughly, weighed $(\mathrm{kg})$ and calculated per net plot grain yield $\mathrm{kg} / \mathrm{plot}$ with the help of shelling $\%$ and moisture $\%$. The grain yield of maize in $\mathrm{kg} / \mathrm{ha}$ was computed from each net plotas following mention formula and finally converted in $\mathrm{q} / \mathrm{ha}$ with divided by 100 from $\mathrm{kg} / \mathrm{ha}$.

Grain yield $(\mathrm{kg} / \mathrm{plot})=\mathrm{A}^{\times} \mathrm{B}^{\times} \mathrm{C}$

Where, $\mathrm{A}=\mathrm{Cob}$ weight $(\mathrm{kg})$

$\mathrm{B}=$ Shelling $\%$

$\mathrm{C}=\left(100^{-} \text {moisture } \%\right)^{\times} 0.0117625$ 
Grain yield $(\mathrm{kg} / \mathrm{ha})=$ Grain yield $(\mathrm{kg} / \mathrm{plot}) \times$ $10,000 \mathrm{~m}^{2} /$ plot size $\left(\mathrm{m}^{2}\right)$

Fodder was weighed (kg/plot) net plot basis. The fodder yield of maize in $\mathrm{kg} / \mathrm{hawas}$ computed from each net plot as below mention formula and finally converted in $\mathrm{q} / \mathrm{ha}$ with divided by $100 \mathrm{in} \mathrm{kg} / \mathrm{ha}$.

Fodder yield $(\mathrm{kg} / \mathrm{ha})=$ Fodder yield $(\mathrm{kg} / \mathrm{plot})$ $\times 10,000 \mathrm{~m}^{2} /$ Plot size $\left(\mathrm{m}^{2}\right)$

The percentage disease control and the percentage deviation in grain and fodder yield were calculated with the help of following formula (Mathur et al., 1971).

Yield increase $(\%)=\frac{\text { Yield in treatment }- \text { Yield in check }}{\text { Yield in treatment }} \times 100$

\section{Results and Discussion}

The disease severity was recorded from ten tagged plants randomly selected from each treatment at 15 days interval after disease initiation. Treatment effect on disease reduction was analyzed on the basis of observation taken seven days after last spray using 1-9 scale as mentioned earlier and the result have been depicted in the Table 2 .

Perusal of data revealed that all the fungicides tested in field condition were significantly reduced disease as compared to control. Minimum per cent disease index (PDI) was recorded in azoxystrobin $18.2 \%+$ difenoconazole $11.4 \%$ SC $(18.15 \%)$ with significantly superior over rest of treatments as well as statistically at par with tebuconazole 25.9 EC (18.89\%), hexaconazole 5 SC $(20.37 \%)$ and carbendazim $12 \%+$ mancozeb 63\% WP recorded 22.22 per cent disease index (PDI). The finding shows that pyraclostrobin $20 \mathrm{WG}$ was recorded 24.81 per cent disease severity which was statistically at par with tebuconazole $50 \%+$ trifloxystrobin
$25 \%$ WG (26.67\%). However, other fungicides viz., fenamidon $10 \%+$ mancozeb $50 \%$ WG recorded 34.44 per cent disease severity were moderately effective. Tebuconazole 10\% + sulphur 65\% WG (47.04\%) followed by azoxystrobin $23 \mathrm{SC}$ $(48.15 \%)$ were found less effective and statistically at par with each other. Whereas, the maximum disease severity 64.81 per cent was recorded in control. The maximum per cent disease reduction over control was recorded in azoxystrobin $18.2 \%+$ difenoconazole $11.4 \%$ SC was 72 per cent followed by tebuconazole 25.9 EC (70.85\%) and hexaconazole 5 SC (68.57\%)and minimum was recorded in tebuconazole $10 \%$ + sulphur $65 \%$ WG (27.42\%) and azoxystrobin $23 \mathrm{SC}(25.71 \%)$.

The maize grain yield was found significantly higher in all treatments as compared to control. The highest yield $38.71 \mathrm{q} / \mathrm{ha}$ was obtained in azoxystrobin $18.2 \%+$ difenoconazole $11.4 \%$ SC treated plots which was statistically at par with tebuconazole 25.9 EC (36.29 q/ha), hexaconazole 5 SC (35.39 q/ha) and carbendazim 12\% + mancozeb 63\% WP $(34.27 \mathrm{q} / \mathrm{ha})$. These are followed by pyraclostrobin 20 WG $(30.93 \mathrm{q} / \mathrm{ha})$, tebuconazole $50 \%+$ trifloxystrobin $25 \%$ WG $(28.44 \mathrm{q} / \mathrm{ha})$ and fenamidon $10 \%+$ mancozeb $50 \%$ WG (27.98q/ha) which all are statistically at par with each other in yield. The minimum yield was recorded in tebuconazole $10 \%+$ sulphur $65 \%(23.85 \mathrm{q} / \mathrm{ha})$ treated plots followed by azoxystrobin $23 \mathrm{SC}$ $(23.77 \mathrm{q} / \mathrm{ha})$. The maximum per centgrain yield was recorded in azoxystrobin 18.2\% + difenoconazole $11.4 \%$ SC was 51.30 per cent followed by tebuconazole 25.9 EC 48.06 per cent and hexaconazole $5 \mathrm{SC}$ was 46.73 per centincrease over control and minimum grain yield was recorded in tebuconazole $10 \%+$ sulphur 65\% WG followed by azoxystrobin 23 SCboth was 20.96per cent increase over control. 
Table.1 List of fungicides evaluated against turcicum leaf blight of maize under artificial inoculated condition

\begin{tabular}{|c|l|c|}
\hline Tr. No. & \multicolumn{1}{|c|}{ Fungicides } & Concent-rations (\%) \\
\hline $\mathbf{T}_{\mathbf{1}}$ & Tebuconazole 25.9 EC & 0.1 \\
\hline $\mathbf{T}_{\mathbf{2}}$ & Hexaconazole 5 SC & 0.1 \\
\hline $\mathbf{T}_{\mathbf{3}}$ & Pyraclostrobin 20 WG & 0.1 \\
\hline $\mathbf{T}_{\mathbf{4}}$ & Azoxystrobin 23 SC & 0.1 \\
\hline $\mathbf{T}_{\mathbf{5}}$ & Azoxystrobin 18.2\% + Difenoconazole 11.4\% SC & 0.25 \\
\hline $\mathbf{T}_{\mathbf{6}}$ & Tebuconazole 10\% + Sulphur 65\% WG & 0.25 \\
\hline $\mathbf{T}_{\mathbf{7}}$ & Tebuconazole 50\% + Trifloxystrobin 25\% WG & 0.25 \\
\hline $\mathbf{T}_{\mathbf{8}}$ & Fenamidon 10\% + Mancozeb 50\% WG & 0.25 \\
\hline $\mathbf{T}_{\mathbf{9}}$ & Carbendazim 12\% + Mancozeb 63\% WP & 0.25 \\
\hline $\mathbf{T}_{\mathbf{1 0}}$ & Untreated (Control) & - \\
\hline
\end{tabular}

Table.2 Effect of different fungicides on turcicum leaf blight disease severity, grain yield and fodder yield under field condition

\begin{tabular}{|c|c|c|c|c|c|c|c|c|}
\hline \multirow{2}{*}{$\begin{array}{l}\text { Tr. } \\
\text { No }\end{array}$} & \multirow[t]{2}{*}{ Fungicides } & \multirow{2}{*}{$\begin{array}{c}\text { Concentra } \\
\text { tion }(\%)\end{array}$} & \multirow{2}{*}{$\begin{array}{c}\text { Disease } \\
\text { severity* }\end{array}$} & \multirow{2}{*}{$\begin{array}{c}\text { Disease } \\
\text { reduction over } \\
\text { control }(\%)\end{array}$} & \multicolumn{2}{|c|}{ Yield $(\mathbf{q} / \mathbf{h a})^{*}$} & \multirow{2}{*}{$\begin{array}{c}\text { Fodder yield } \\
\text { increased over } \\
\text { control (\%) }\end{array}$} & \multirow{2}{*}{$\begin{array}{c}\text { Grain yield } \\
\text { increased over } \\
\text { control }(\%)\end{array}$} \\
\hline & & & & & $\begin{array}{l}\text { Grain } \\
\text { Yield }\end{array}$ & $\begin{array}{c}\text { Fodder } \\
\text { yield }\end{array}$ & & \\
\hline $\mathbf{T}_{1}$ & Tebuconazole $25.9 \mathrm{EC}$ & 0.1 & $25.71^{\mathrm{ab}}(18.89)$ & 70.85 & $36.29^{\mathrm{ab}}$ & $176.24^{\mathrm{a}}$ & 50.70 & 48.06 \\
\hline $\mathbf{T}_{2}$ & Hexaconazole $5 \mathrm{SC}$ & 0.1 & $\left.26.78^{\mathrm{abc}} 20.37\right)$ & 68.57 & $35.39^{\mathrm{abc}}$ & $161.78^{\mathrm{ab}}$ & 46.29 & 46.73 \\
\hline $\mathbf{T}_{3}$ & Pyraclostrobin $20 \mathrm{WG}$ & 0.1 & $29.84^{\text {bc }}(24.81)$ & 61.71 & $30.93^{\mathrm{bcd}}$ & $133.20^{\mathrm{bcd}}$ & 34.77 & 39.05 \\
\hline $\mathbf{T}_{4}$ & Azoxystrobin $23 \mathrm{SC}$ & 0.1 & $43.93^{\mathrm{e}}(48.15)$ & 25.71 & $23.77^{\mathrm{et}}$ & $90.29^{\mathrm{e}}$ & 3.76 & 20.69 \\
\hline $\mathbf{T}_{5}$ & Azoxystrobin $18.2 \%$ + Difenoconazole $11.4 \%$ SC & 0.25 & $25.20^{\mathrm{a}}(18.15)$ & 72.00 & $38.71^{\mathrm{a}}$ & $182.75^{\mathrm{a}}$ & 52.46 & 51.30 \\
\hline $\mathbf{T}_{6}$ & Tebuconazole $10 \%+$ Sulphur $65 \%$ WG & 0.25 & $43.30^{\mathrm{e}}(47.04)$ & 27.42 & $23.85^{\text {det }}$ & $102.27^{\mathrm{de}}$ & 15.04 & 20.96 \\
\hline $\mathbf{T}_{7}$ & Tebuconazole 50\% + Trifloxystrobin 25\% WG & 0.25 & $31.08^{\mathrm{c}}(26.67)$ & 58.85 & $28.44^{\text {cde }}$ & $124.53^{\mathrm{cd}}$ & 30.23 & 33.72 \\
\hline $\mathbf{T}_{8}$ & Fenamidon 10\% + Mancozeb 50\% WG & 0.25 & $35.91^{\mathrm{d}}(34.44)$ & 46.85 & $27.98^{\text {cde }}$ & $112.55^{\text {cde }}$ & 22.80 & 32.63 \\
\hline $\mathbf{T}_{9}$ & Carbendazim 12\% + Mancozeb 63\% WP & 0.25 & $28.09^{\mathrm{abc}}(22.22)$ & 65.71 & $34.27^{\mathrm{abc}}$ & $138.22^{\mathrm{bc}}$ & 37.14 & 44.99 \\
\hline \multirow[t]{4}{*}{$\mathbf{T}_{10}$} & Untreated (Control) & & $53.66^{\mathrm{t}}(64.81)$ & - & $18.85^{\mathrm{t}}$ & $80.89^{\mathrm{e}}$ & - & - \\
\hline & S.Em. \pm & & 1.32 & - & 2.24 & 10.49 & - & - \\
\hline & C.D. at $5 \%$ & & 3.92 & - & 6.64 & 31.16 & - & - \\
\hline & C.V. \% & & 6.65 & - & 12.97 & 13.94 & - & - \\
\hline
\end{tabular}




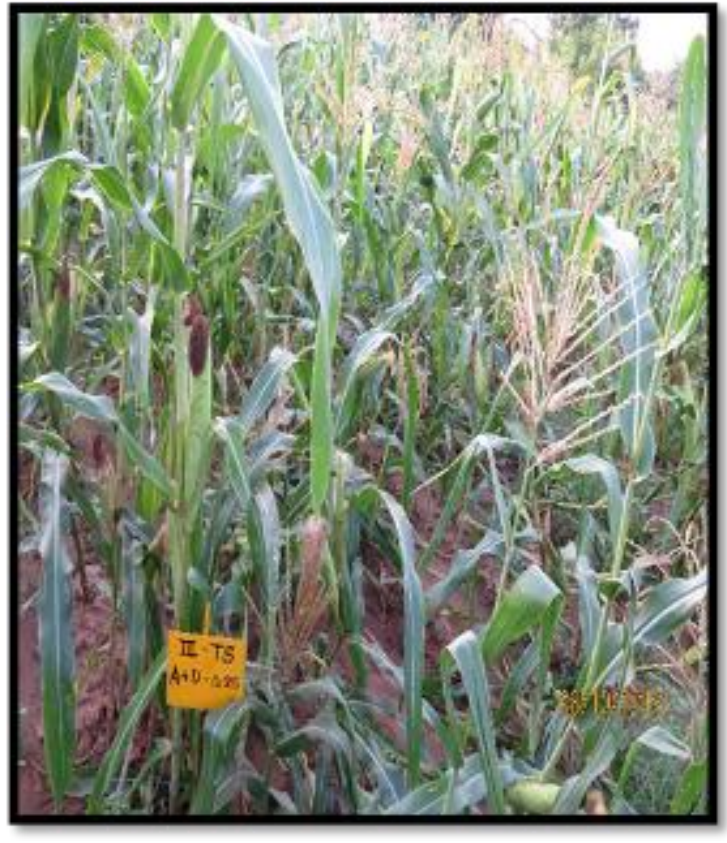

Azoxystrobin 18.2\% + Difenoconazole $11.4 \% \mathrm{SC}$

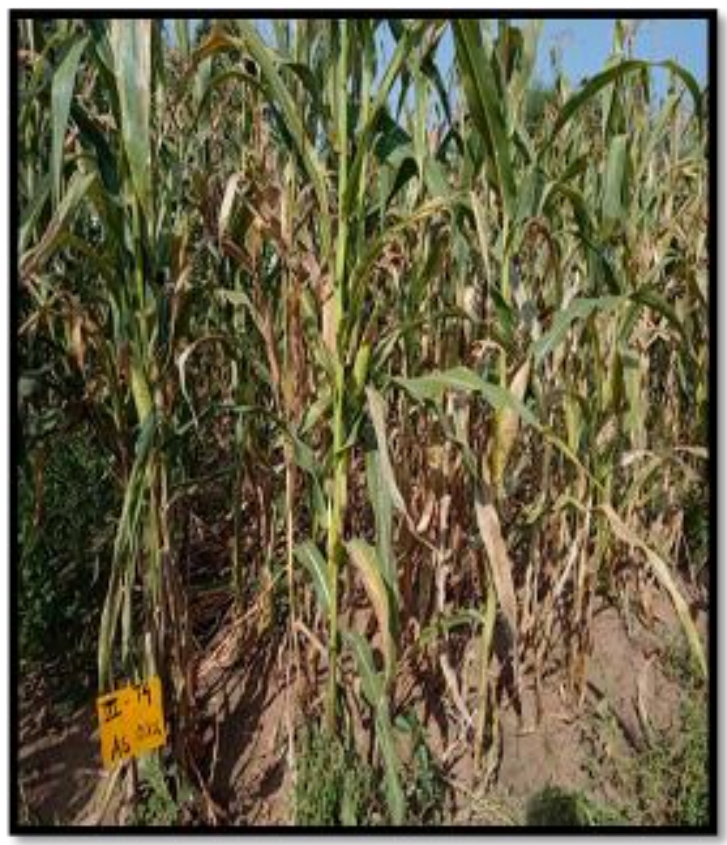

Azoxystrobin 23 SC

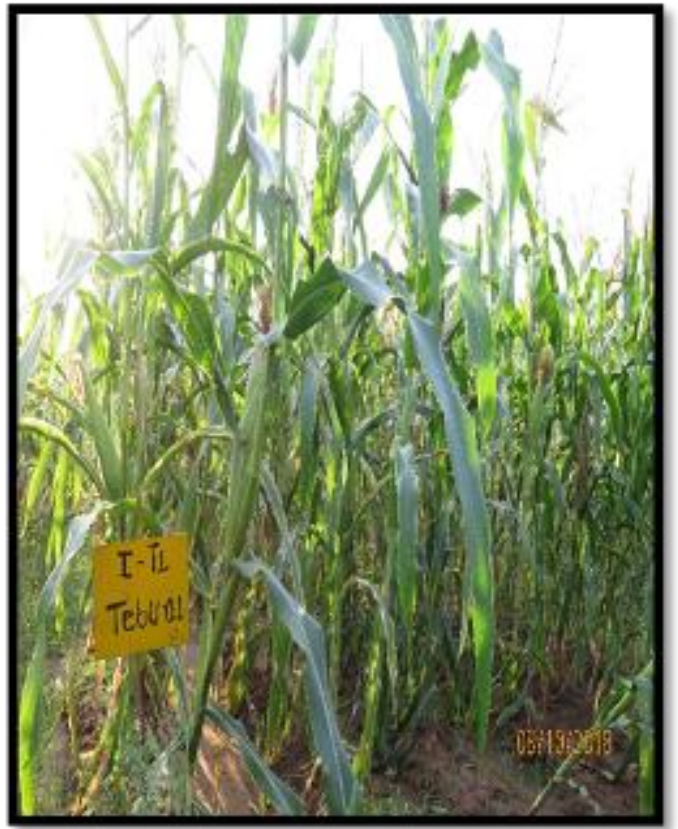

Tebuconazole 25.9 EC

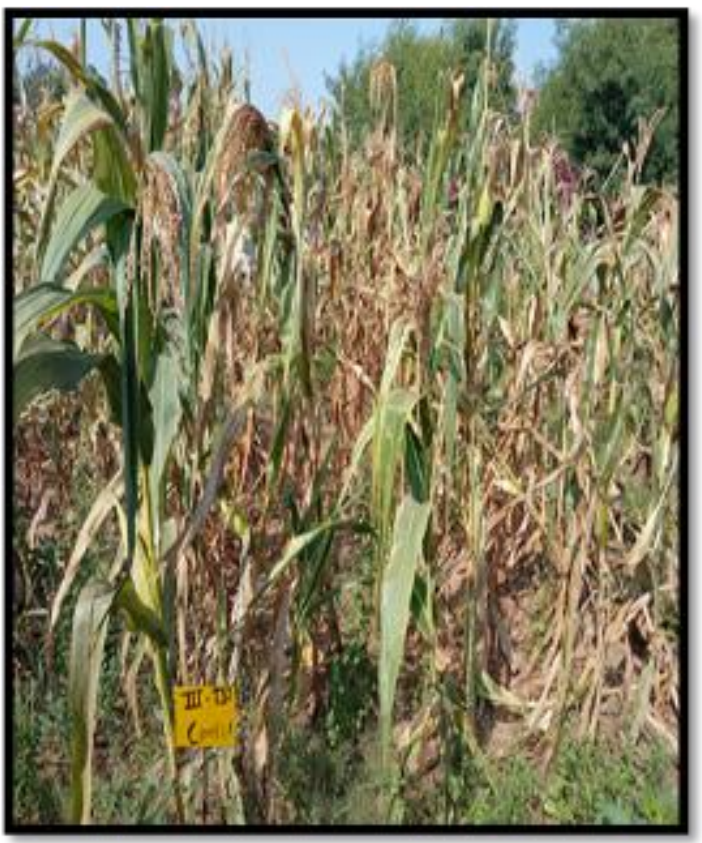

Control

Plate.1 Effect of different fungicides against turcicum leaf blight (E. turcicum) on maize under epiphytotic field condition 
Fodder yield of maize as like as grain yield was found significantly higher in all treatments as compared to control. The highest fodder yield $182.75 \mathrm{q} / \mathrm{ha}$ was obtained in azoxystrobin $18.2 \%$ + difenoconazole $11.4 \%$ SC treated plots which was statistically at par with tebuconazole 25.9 EC (176.24 q/ha) and hexaconazole 5 SC (161.78 q/ha). These are followed by carbendazim $12 \%+$ mancozeb $63 \%$ WP (138.22q/ha) which was statistically at par with pyraclostrobin 20 WG $(133.20 \quad \mathrm{q} / \mathrm{ha})$, tebuconazole $50 \%$ + trifloxystrobin $25 \% \mathrm{WG}$ $(124.53 \mathrm{q} / \mathrm{ha})$ and fenamidon $10 \%+$ mancozeb $50 \%$ WG (112.55q/ha) was statistically at par with each other in fodder yield.

The minimum fodder yield was recorded in tebuconazole $10 \%+$ sulphur $65 \% \mathrm{WG}$ and azoxystrobin $23 \mathrm{SC}$ treated plots which resulted 102.27 and $90.29 \mathrm{q} / \mathrm{ha}$, respectively because turcicum leaf blight disease mainly affected the leaf portion. The maximum per cent fodder yield was recorded in azoxystrobin $18.2 \%+$ difenoconazole $11.4 \%$ SC $(52.46 \%)$ followed by tebuconazole 25.9 EC $(50.70 \%)$ and hexaconazole 5 SC (46.29\%)and minimum in azoxystrobin 23 SC (3.76\%) increase over control. These result revealed that significantly higher grain yield, fodder yield and minimum disease severity were obtained in azoxystrobin $18.2 \%$ + difenoconazole $11.4 \%$ SC treated plot over control.

The denouement recorded are in close agreement with those obtained by Wani et al., (2017) studied on twelve fungicides shows that the two foliar sprays with non-systemic fungicide, mancozeb 75 WP @ 0.25 per cent was recorded minimum disease severity 5.69 per cent in and maximum grain yield $52.50 \mathrm{q} / \mathrm{ha}$ followed by systemic fungicide, propiconazole 25 EC @ $0.1 \%$ concentration diseased severity was 6.11 per cent and grain yield 52.25 q/haas compared to control plot was recorded maximum 20.45 per cent disease severity and minimum grain yield $45.20 \mathrm{q} / \mathrm{ha}$.

Reddy et al., (2013) exhibited the treatment mancozeb 75 WP @0.25\% and combination treatments of carbendazim 12\% + mancozeb 63\% WP @ 0.25\% was recorded the lowest per cent disease index reducing the disease by $73.0 \%$ and $72.1 \%$, respectively. The congruous results observed by Patil (2000) that systemic and non-systemic fungicides difenoconazole, hexaconazole and mancozeb given best results in field conditions. Rahman et al., (1993) tested five fungicides from which propiconazole 25 ECwas effective in reduced disease severity in the field condition. Kumar and Mauriya (2015) descried that Zineb 75 WP @ 0.25\% concentration and mancozeb 63\%+ carbendazim 12\%@0.25\% was found most effective reduce disease severity and ultimately produced higher grain yield of maize. Pinto (1997) found that the tebuconazole 25.9 EC and mancozeb 75 WP was found effective for controlling disease severity in field condition

\section{Acknowledgment}

The financial support from Main Maize Research station, Godhra, AAU, Anandand Directorate of Research and Dean PG, AAU, Anand is gratefully acknowledged.

\section{References}

Chenulu, V.V., and Hora, T.S. 1962. Studies on losses due to Helminthosporium blight of maize. Indian Phytopathology. 15: 235237.

Chung, C. L., J. M. Longfellow, E. K. Walsh, Z. Kerdieh, G. Van Esbroeck, P. BalintKurti, and Nelson, R. J. 2010. Resistance loci affecting distinct stages of fungal pathogenesis: use of introgression lines for QTL mapping and characterization in the maize-Setosphaeria turcica pathosystem. BMC Plant Biology. 10(1): 103.

Jha, M. M. 1993. Assessment of losses due to maize diseases in widely grown maize cultivars at Dholi. $18^{\text {th }}$ Annual Progress Report on Rabi Maize, AICMIP. Indian Agricultural Research Institute, New Delhi. 138-139.

Kumar, S., and Mauriya, A. K. 2015. Effect of 
fungicides and plant extracts for management of turcicum leaf blight of maize. The Bioscan. 10(56.40):48-70.

Mathur, R. L., G. Singh, and Gupta R. B. L. 1971. Field evaluation of fungicides for the control of powdery mildew of pea. Indian Journal of Mycology and Plant Pathology. 1(2): 95-98.

Mitiku, M., Y. Eshte, and Shiferaw W. 2014. Evaluation of maize variety for northern leaf blight (Trichometasphaeria turcica) in South Omo zone. World Journal of Agricultural Research. 2(5): 237-239.

Patil, V. S.2000. Epidemiology and management of leaf blight of wheat caused by exserolilum hawiiensis (Bugnicourt) subram and Jain ex MB ellis. Ph. D. dissertation, University of Agricultural Sciences; Dharwad, Tamil Nadu, India

Pinto,N. D. A. 1997. Evaluation of fungicides for the control of corn foliar diseases. Summa Phytopathologica.
23(3/4): 271-274.

Rahman, M. H, L. A. Begum, K. B. Alam, and Khan A. L. 1993. Efficacy of fungicides to control turcicum leaf blight of maize. Bangladesh Journal of Plant Pathology. 9(1-2): 35-36.

Reddy, T., P . Reddy, R. Reddy, and Reddy, S. 2013. Management of turcicum leaf blight of maize caused by Exserohilum turcicum in maize. International Journal of Scientific and Research Publications. 3: 2250-3153.

Wani, T. A., M. Ahmad, and Anwar, A. 2017. Evaluation of fungicides, bioagents and plant extracts against Exserohilum turcicum causing turcicum leaf blight of maize. International Journal of Current Microbiology and Applied Science. 6(8): 2754-2762.

Wheeler, B. E. J. 1969. An introduction to plant disease. John Wiley Sons Limited, London. Pp. 301.

\section{How to cite this article:}

Barad, A.J., S.K. Singh, G.J. Bhagora and Barad, A.H. 2019. Efficacy of Different Fungicides against Exserohilum turcicum Causing Turcicum Leaf Blight Disease in Maize. Int.J.Curr.Microbiol.App.Sci. 8(08): 108-114. doi: https://doi.org/10.20546/ijcmas.2019.808.013 